\title{
Early Cretaceous alkaline/ultra-alkaline silicate and carbonatite magmatism in the Indian Shield - a review: implications for a possible remnant of the Greater Kerguelen Large Igneous Province
}

Department of Geology, Centre of Advanced Study, Institute of Science, Banaras Hindu University, Varanasi 221005, India;

Email: rajeshgeolbhu@gmail.com

(Received : 12/01/2019; Revised accepted : 24/07/2019)

https://doi.org/10.18814/epiiugs/2020/020017

\section{ABSTRACT}

The early Cretaceous (ca. 118-100 Ma) alkaline/ultraalkaline silicate and carbonatite magmatism, exclusively recorded in the Chhotanagpur Gneissic Complex and the Shillong Plateau-Mikir Hills in the eastern/northeastern regions of the Indian Shield, have been reviewed to understand their genetic aspects. These are thought to be associated to the Kerguelen hot spot, active in this region during ca. 118-100 Ma. The existing geochemical, geochronological and isotopic data do not support any definite emplacement order for these diverse groups of magmatic suites. It is likely that they were derived from distinct magma batches with direct or indirect involvement of the Kerguelen plume. The available data suggest their possible derivation from the depleted asthenosphere/lithosphere with negligible contribution from the Kerguelen mantle plume. It is likely that mantle plume provided additional heat necessary to melt the asthenosphere/lithosphere. These data also suggest effects of low-pressure crustal contamination, crystal accumulation and fractional crystallization, rather than mantle-derived heterogeneity. These identified magmatic events together with other known magmatic events such as southeastern Tibet, Abor volcanics, SW Australia and eastern Antarctica during ca. 140-100 Ma could be related to the Kerguelen plume and integral part of the Greater Kerguelen Large Igneous Province, and have possible impact on the breakup of East Gondwanaland.

\section{Introduction}

Genetic linkage between the spatially associated carbonatite and alkaline/ultra-alkaline silicate rocks is directly related to the nature and source of melts and their crystallization history. The origin of carbonated silicate melts through liquid-immiscibility or fractional crystallization suggest genetic connection between carbonate and silicate derivatives, whereas direct genetic connection between these two rocks is uncertain if derived directly from low-degree partial melts of carbonated mantle peridotite at deeper level (cf. Bell et al., 1998; Gittins and Harmer, 2003; Srivastava et al., 2005; Mitchell, 2005; Melluso et al., 2010; Beccaluva et al., 2017). Furthermore, the spatial and temporal connections between carbonatites and Large Igneous Provinces (LIPs), and ultimately to plume tectonics, are also well established (e.g. Simonetti et al., 1998; Bell and Tilton, 2001; Campbell, 2005; Ernst, 2014; Bryan and Ernst, 2008; Ernst and Bell, 2010). The Indian examples of such association include:

(i) The Réunion plume induced ca. 65 Ma Deccan LIP and associated carbonatite-alkaline rock complexes (e.g. Simonetti et al., 1998; Ray and Pande, 1999) and kimberlites (e.g. Lehmann et al., 2010; Chalapathi Rao et al., 2011),

(ii) The Kerguelen plume induced ca. 118-100 Ma RajmahalSylhet Traps (e.g. Ray et al., 2005; Ghatak and Basu, 2011) and associated carbonatite-alkaline rock complexes (e.g. Srivastava et al., 2005; Srivastava and Sinha, 2007; Ghatak and Basu, 2013) and potassic-mafic intrusions (e.g. Kent et al., 1998; Mitchell, 2007; Mitchell and Fareeduddin, 2009; Chalapathi Rao et al., 2014; Srivastava et al., 2016). These are thought to be part of the Comie-Bunbury LIP (Zhu et al., 2009) ( $a k a$ Greater Kerguelen LIP; Olierook et al., 2017), and

(iii) A late Mesoproterozoic plume related ca. 1.12-1.05 Ga LIP (e.g. Ernst, 2014; Samal et al., 2019), which includes kimberlites (e.g. Chalapathi Rao et al., 2013a) and lamproites (e.g. Chalapathi Rao et al., 2016) intrusions.

In this communication, an attempt has been made to provide a comprehensive appraisal on petrological, geochemical, geochronological and isotopic characteristics of the early Cretaceous alkaline/ultra-alkaline-carbonatite magmatism recorded in the Indian Shield (exclusively in eastern and northeastern regions) to understand their genetic aspects. Their possible relation with the recently 
identified Greater Kerguelen Large Igneous Province (LIP) and breakup of the East Gondwanaland are also discussed.

\section{Geological Background}

The Indian Shield is a composite ensemble of Archean cratonic blocks, tectonically girdled with Meso- to Neoproterozoic mobile belts (Fig. 1). The major cratonic blocks are Dharwar, Bastar, Singhbhum, Bundelkhand, Aravalli and Shillong Plateau-Mikir Hills (cf. Naqvi and Rogers, 1987; Sharma, 2009; Ramakrishnan and Vaidyanadhan, 2010). Amongst these, the Singhbhum craton (consisting of the Singhbhum Granite Complex, the Chhotanagpur Gneissic Complex, and the Singhbhum Mobile Belt) and the Shillong Plateau-Mikir Hills in eastern and northeastern region of Indian Shield exclusively recorded the early Cretaceous alkaline/ultra-alkaline-carbonatite magmatic activities (Fig. 2a and 2b).

The Chhotanagpur Gneissic Complex (CGC), considered as a cratonized mobile belt (e.g. Sharma, 2009; Srivastava et al., 2014; Chalapathi Rao et al., 2014), has recorded a continuum of polyphase tectono-magmatic activity from Archean to early Cretaceous manifested in the form of (i) Archean magmatic events spurred with spinifix textured volcanic activity (e.g. Bhattacharya et al., 2010), (ii) Mesoproterozoic magmatism emplaced in an extensional tectonic regime (e.g. Srivastava et al., 2012), (iii) within-plate setting early Cretaceous potassic/ultrapotassic and basic intrusions (cf. Kent et al., 2002; Srivastava et al., 2009, 2014; Chalapathi Rao et al., 2014), and (iv) early Cretaceous Rajmahal (-Sylhet) traps (cf. Kent et al., 1997; Ghatak and Basu, 2011).

The Shillong Plateau and the Mikir Hills (SPMH) share almost similar geological features in the form of Archean gneisses, Proterozoic mafic dykes, Shillong Group of rocks, 700-450 Ma granite plutons (intruding the gneissic basement as well as the Shillong Group cover), the early Cretaceous Sylhet Traps, a number of ultramafic-alkaline-carbonatite complexes, and potassic lamprophyre (e.g. Nambiar, 1988; Kumar et al., 1996; Das Gupta and Biswas, 2000; Srivastava and Sinha, 2004a,b; Ghatak and Basu, 2011; Srivastava et al., 2016, 2019 and references therein; see Fig. 2).

\section{Petrological and Geochemical Characteristics}

A number of radiometric ages on the early Cretaceous alkaline/ ultra-alkaline-carbonatite (Table 1) and mafic (Table 2) magmatic rocks, emplaced within the CGC and/or the SPMH, suggests that the
Kerguelen hot spot was active in this region over a protracted period of ca. $18 \mathrm{Ma}$, i.e. between ca. $118 \mathrm{Ma}$ and ca. $110 \mathrm{Ma}$, and experienced several magmatic activities in this parts of the Indian Shield. The three major components of these magmatic intrusions, viz. (i) ultrapotassic, (ii) silicate (ultramafic-alkaline)-carbonatite complexes, and (iii) mafic, are described in subsequent sections.

\section{Ultrapotassic intrusive}

The Early Cretaceous (ca. 115-114 Ma) ultrapotassic dykes are pervasively emplaced in the CGC, particularly within the Damodar Valley Gondwana sedimentary basins (Fig. 2; cf. Kent et al., 1998; Coffin et al., 2002; Srivastava et al. 2009; Chalapathi Rao et al., 2014). They show porphyritic texture and composed of pseudomorphosed olivine, phlogopite-biotite, diopside, amphibole, Cr-spinel, K-feldspar, calcite, apatite, rutile, $\mathrm{Mg}$-ilmenite, chlorite, serpentine, and iron oxides/sulphides in varying proportions. K-rich titanate is also recorded in a couple of samples (Chalapathi Rao et al., 2013b). These intrusive rocks are variously referred to as mica-traps, mica-peridotites, 


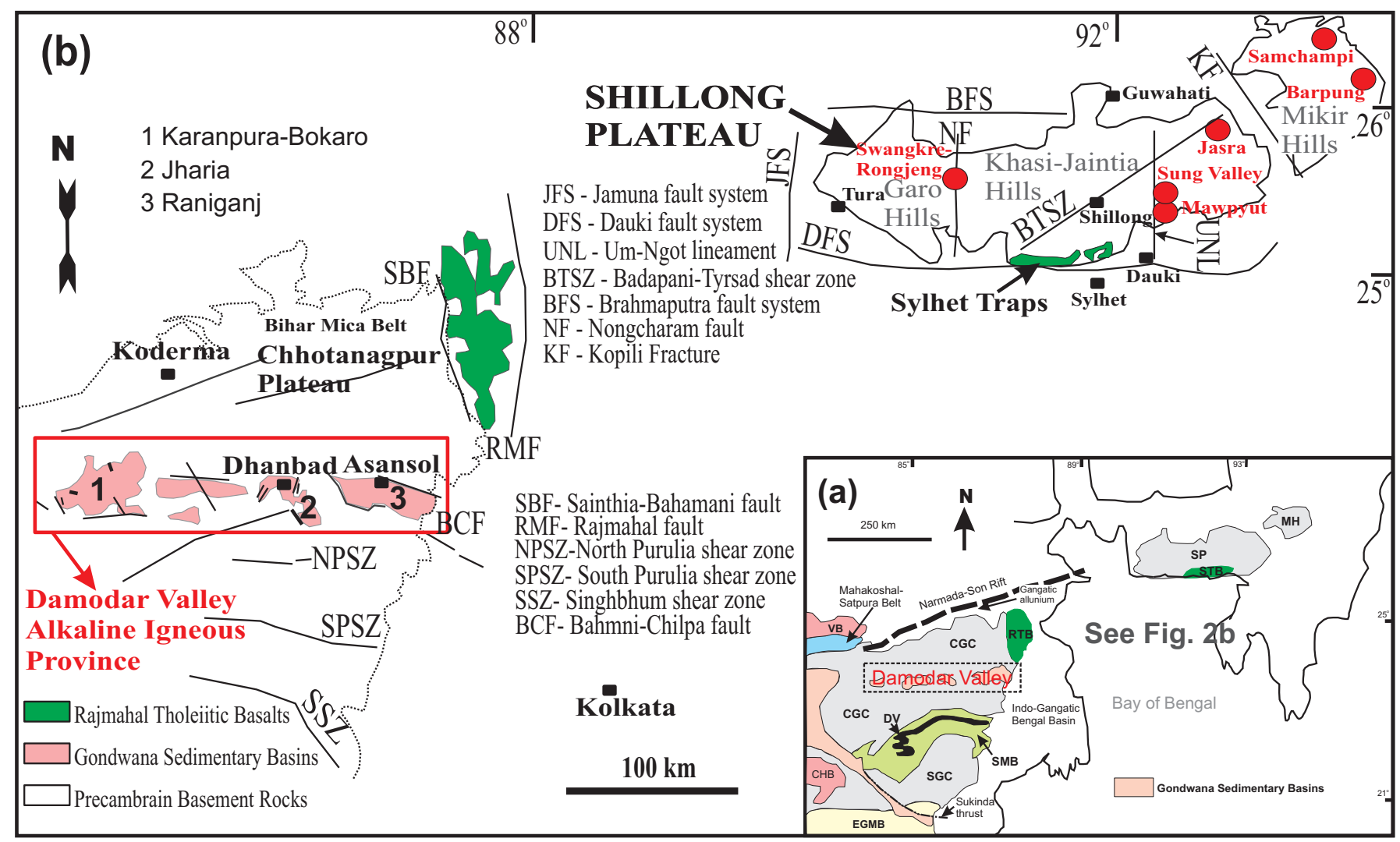

Figure 2. (a) Geological sketch map of the eastern and north-eastern region of the Indian Shield (simplified from Bhowmik et al., 2012). CGC, Chhotanagpur Gneissic Complex; CHB, Chhattisgarh basin; DV, Dalma volcanic; EGMB, Eastern Ghats Mobile Belt; MH, Mikir Hills; RTB, Rajmahal tholeiitic basalt; SGC, Singhbhum Granite Complex; SMB, Singhbhum Mobile Belt; SP, Shillong Plateau; STB, Sylhet tholeiitic basalt; V, Vindhyan Basin. (b) Enlarged geological sketch map of the eastern and north-eastern India showing the locations of early Cretaceous magmatic activity in the Damodar Valley, Rajmahal-Sylhet tholeiitic basalts, Shillong Plateau, and Mikir Hills (modified after Melluso et al., 2012; Srivastava et al., 2016, 2019).

Table 1: Available radiometric ages on the Kerguelen plume induced early Cretaceous alkaline/ultra-alkaline-carbonatite magmatic rocks in the eastern and north-eastern Indian shield.

\begin{tabular}{|c|c|c|c|c|c|}
\hline & Area/Region & Dated rock/mineral & Age in $M a$ & Method & Reference \\
\hline 1. & Damodar Valley, CGC & Whole rock Orangeites & $113.5 \pm 0.5$ & Ar-Ar laser probe & Kent et al. (1998) \\
\hline 2. & Damodar Valley, CGC & Whole rock Lamprophyre & $114.9 \pm 0.3$ & Ar-Ar* & Coffin et al. (2002) \\
\hline 3. & Sung Valley, SP & $\begin{array}{l}\text { Whole rock pyroxenite and } \\
\text { phlogopite from carbonatite }\end{array}$ & $107.2 \pm 0.8$ & Ar-Ar* & Ray et al. (1999) \\
\hline 4. & Sung Valley, SP & $\begin{array}{l}\text { Whole rock carbonatite and } \\
\text { pyroxenite, and phlogopite from } \\
\text { carbonatite }\end{array}$ & $106 \pm 11$ & $\mathrm{Rb}-\mathrm{Sr}$ & Ray et al. (2000) \\
\hline 5. & Sung Valley, SP & Perovskite from ijolite & $115.1 \pm 5.1$ & $\mathrm{U}-\mathrm{Pb}$ & Srivastava et al. (2005) \\
\hline 6. & Sung Valley, SP & Perovskite from ijolite & $104.0 \pm 1.3$ & In situ U-Pb SIMS & Srivastava et al. (2019) \\
\hline 7. & Sung Valley, SP & Perovskite from dunit & $109.1 \pm 1.6$ & In situ U-Pb SIMS & Srivastava et al. (2019) \\
\hline 8. & Sung Valley, SP & Perovskite from uncompahgrite & $101.7 \pm 3.6$ & In situ U-Pb SIMS & Srivastava et al. (2019) \\
\hline 9. & Sung Valley, SP & Zircon from nepheline syenite & $106.8 \pm 1.5$ & In situ U-Pb SIMS & Srivastava et al. (2019) \\
\hline 10. & Jasra, SP & Zircon and baddeleyite from gabbro & $105.2 \pm 0.5$ & U-Pb TIMS & Heaman et al. (2002) \\
\hline 11. & Jasra, SP & Zircon from syenite & $106.8 \pm 0.8$ & In situ U-Pb SIMS & Srivastava et al. (2019) \\
\hline 12. & Jasra, SP & Perovskite from clinopyroxenite & $101.6 \pm 1.2$ & In situ U-Pb SIMS & Srivastava et al. (2019) \\
\hline 13. & Swangkre, SP & Whole rock lamprophyre & $107 \pm 4$ & $\mathrm{~K}-\mathrm{Ar}$ & Sarkar et al. (1996) \\
\hline
\end{tabular}

* Plateau ages; CGC: Chotanagpur Gneissic Complex; SP: Shillong plateau 
Table 2: Available radiometric ages on the Kerguelen plume induced early Cretaceous mafic magmatic rocks in the eastern and north-eastern Indian shield.

\begin{tabular}{|c|c|c|c|c|c|}
\hline & Area/Region & Dated rock/mineral & Age in $M a$ & Method & Reference \\
\hline 1. & RB, CGC & Whole rock (basaltic flow) & $116.2 \pm 0.6$ & $\mathrm{Ar}-\mathrm{Ar} *$ & Pringle et al. (1994) \\
\hline 2. & $\mathrm{RB}, \mathrm{CGC}$ & Whole rock (basaltic flow) & $117.5 \pm 0.5$ & Ar-Ar* & Baksi (1995) \\
\hline 3. & $\begin{array}{l}\text { Galsi, Bengal basin } \\
\text { borehole basalt }\end{array}$ & Whole rock (basaltic flow) & $117.1 \pm 0.4$ & Ar-Ar* & Baksi (1995) \\
\hline 4. & $\begin{array}{l}\text { Jalangi, Bengal basin } \\
\text { borehole basalt }\end{array}$ & Whole rock (basaltic flow) & $116.9 \pm 2.3$ & Ar-Ar* & Baksi (1995) \\
\hline 5. & Raniganj basin, CGC & Whole rock (dolerite dyke) & $112.5 \pm 0.5$ & Ar-Ar* & Kent et al. (2002) \\
\hline 6. & Koderma, CGC & Whole rock (dolerite dyke) & $115.3 \pm 0.4$ & Ar-Ar* & Kent et al. (2002) \\
\hline 7. & Dhanbad, RB, CGC & Whole rock (basaltic flow) & $117.9 \pm 0.4$ & Ar-Ar* & Kent et al. (2002) \\
\hline 8. & Mirza Cauki, RB, CGC & Whole rock (basaltic flow) & $117.4 \pm 0.5$ & Ar-Ar* & Kent et al. (2002) \\
\hline 9. & Mirza Cauki, RB, CGC & Whole rock (basaltic flow) & $112.2 \pm 0.5$ & Ar-Ar* & Kent et al. (2002) \\
\hline 10. & Lalmatia, RB, CGC & Whole rock (basaltic flow) & $105 \pm 0.5$ & Ar-Ar* & Kent et al. (2002) \\
\hline 11. & Mahadeogan, RB, CGC & Whole rock (basaltic flow) & $115.3 \pm 0.6$ & Ar-Ar* & Kent et al. (2002) \\
\hline 12. & Gogra Hill, RB, CGC & Whole rock (basaltic flow) & $102.8 \pm 1.8$ & Ar-Ar* & Kent et al. (2002) \\
\hline 13. & Sitalpur, RB, CGC & Whole rock (basaltic flow) & $109.6 \pm 0.8$ & Ar-Ar* & Kent et al. (2002) \\
\hline 14. & Kunda Pahar, RB, CGC & Whole rock (basaltic flow) & $118.2 \pm 0.3$ & Ar-Ar* & Coffin et al. (2002) \\
\hline 15. & Sylhet trap & Whole rock (basaltic flow) & $110 \pm 3$ & $\mathrm{~K}-\mathrm{Ar}$ & Sarkar et al. (1996) \\
\hline
\end{tabular}

* Plateau ages; CGC: Chotanagpur Gneissic Complex; SP: Shillong plateau; RB: Rajmahal basaltic flow

lamprophyres, glimmerites, orangeites, lamproites and ultramafic lamprophyre (aillikite) (e.g. Middlemost et al., 1988; Rock and Paul, 1989; Rock et al., 1992; Kent et al., 1998; Jia et al., 2003; Mitchell and Fareeduddin, 2009; Srivastava et al., 2009; Chalapathi Rao et al., 2014). However, mineral chemistry of these ultrapotassic intrusive rocks suggests their lamproitic nature; not orangeitic and kimberlitic characteristics (see Fig. 4; Chalapathi Rao et al., 2014). These studies suggest that both plume component and ancient subduction event have affected diverse nature of ultrapotassic rocks. Small degreepartial melting of a metasomatically veined and thinned lithosphere, probably depleted garnet bearing harzburgitic source modified through metasomatism by carbonate- and rutile-rich fluids/melts via Kerguelen plume, have produced diverse nature of ultrapotassic rocks (e.g. Srivastava et al., 2009; Mitchell and Fareeduddin, 2009; Chalapathi Rao et al., 2014).

A lamprophyre dyke, reported from the East Garo Hills, Shillong Plateau (Nambiar, 1988; Srivastava et al., 2016) is composed of large phenocrysts of clinopyroxene and phlogopite with lower amounts of amphibole, olivine and Fe-Ti oxides in a groundmass of clinopyroxene, phlogopite, apatite, and alkali feldspar. Carbonates, analcime, other zeolites and rutile are secondary minerals. This dyke

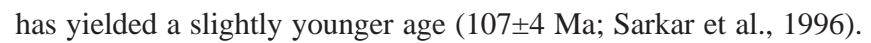
Earlier it was believed that this might be contemporaneous to the ultrapotassic dykes of the CGC (Nambiar, 1988). However detailed studies by Srivastava et al. (2016) suggest that it is distinctly different from that of the Damodar Valley lamproites (see Fig. 5) and derived from a heterogenous lithospheric mantle sources rather than input of plume-related magmatism.

\section{Silicate (ultramafic-alkaline)-carbonatite complexes}

Four early Cretaceous (ca. 115-101 Ma) silicate-carbonatite magmatic intrusions are emplaced within the Shillong Plateau-Mikir
Hills (Fig. 2; e.g. Srivastava et al., 2019), which include (i) Sung Valley, (ii) Jasra, (iii) Swangkre-Rongjeng, and (iv) Mawpyut. The Sung Valley and Jasra complexes have been studied in detail for their petrological, geochemical, and geochronological accounts and discussed origin of different units of these two complexes. Although many earlier workers favored co-genetic nature of the Sung Valley complex formed through the late-stage liquid immiscibility (e.g. Veena et al., 1998; Ray et al., 2000), however, later studies advocated that different rock units were crystallized from batches of independent magmas with distinct magmatic affinity (Srivastava and Sinha, 2004a; Srivastava et al., 2005, 2019; Melluso et al., 2010). The latter theory is well supported by field-setting (Srivastava and Sinha, 2004a), mineral chemistry (Melluso et al., 2010; Ghatak and Basu, 2013; see Fig. 5), geochemistry (Srivastava and Sinha, 2004a; Srivastava et al., 2005; see Fig. 6 for distinct rare-earth patterns for different rocks) and geochronology (Ray et al., 1999, 2000; Srivastava et al., 2005, 2019; see Table 1 - distinct intrusions have different emplacement ages).

Different petrogenetic models for the genesis of the Sung Valley and Jasra complexes have been comprehensively reviewed by Srivastava et al. (2005) and Srivastava and Sinha, (2007). However, a model based on experimental results, which is well supported by field setting, geochemistry and isotopic data, is thought to be best explanation for the genesis of such alkaline-carbonatite complexes (cf. Wallace and Green, 1988; Lee and Wyllie, 1997; Wyllie and Lee, 1998; Harmer, 1999; Srivastava et al., 2005; Srivastava and Sinha, 2007), has been proposed (Fig. 7). This model explains that carbonate melts may be generated by direct melting of a carbonated peridotite mantle source at depths equivalent to $\sim 20-35 \mathrm{kbar}$, which could be in equilibrium with phlogopite lherzolite and rich in magnesium and significant amount of alkalies (5-7\%) (cf. Wallace and Green, 1988). This model also demonstrate that how metasomatic clinopyroxene, olivine, and free $\mathrm{CO}_{2}$ fluid could be formed by consuming orthopyroxene (lherzolite) by the melt under equilibrium conditions 


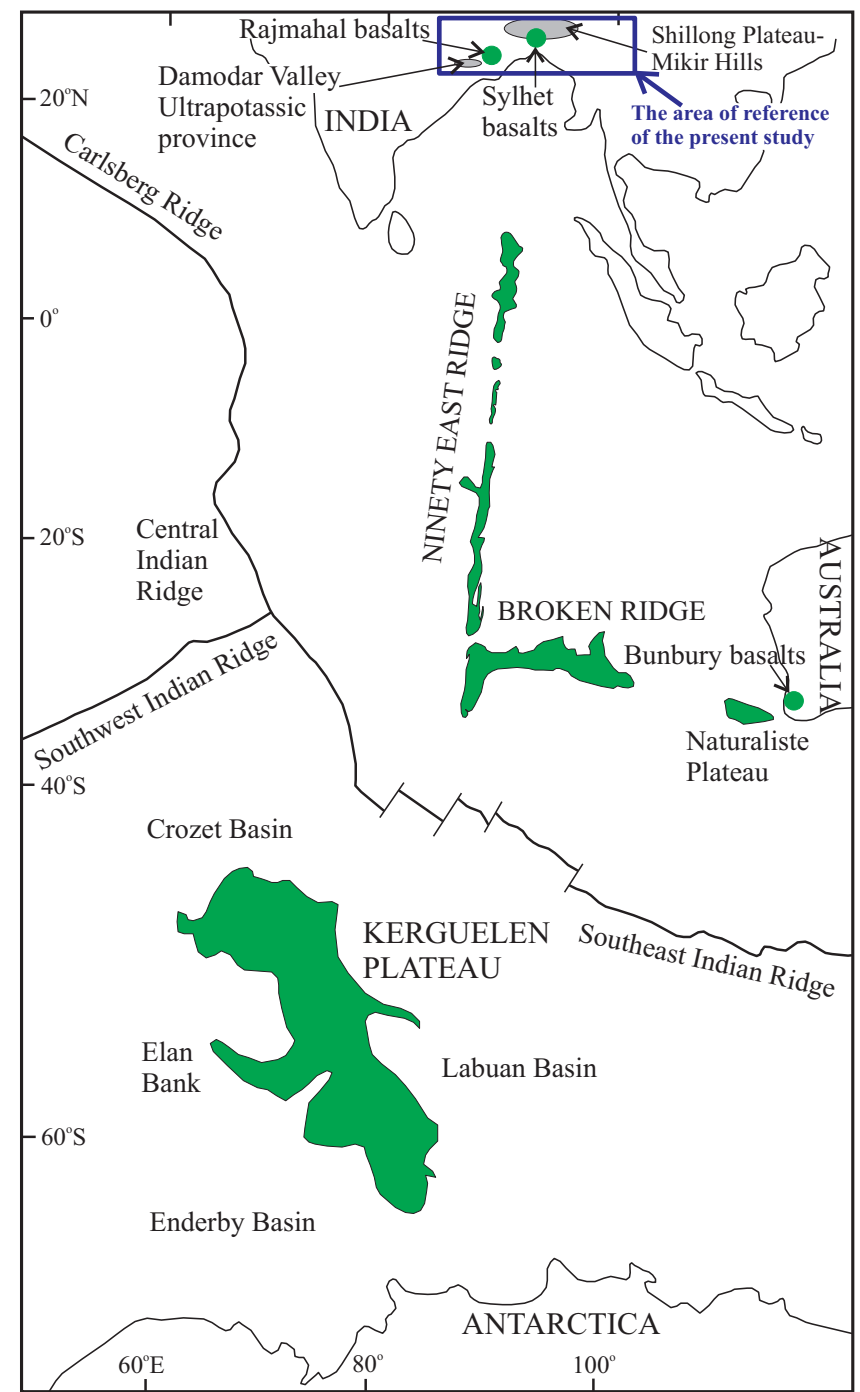

Figure 3. Location of distinct magmatic activities of the Kerguelen plateau, Broken Ridge, Naturaliste plateau, Bunbury, RajmahalSylhet, and associated alkaline/ultra-alkaline silicate and carbonatite magmatisms of the Shillong Plateau-Mikir Hills, supposed to be connected to the Kerguelen hot spot during early Cretaceous (modified from Kent et al., 2002). The box denotes the area of the present study where early Cretaceous (ca. 118-101 Ma) alkaline/ultra-alkaline silicate and carbonatite activities are recorded in the Indian Shield.

at 20 kbar that metasomatizes the lherzolite to an alkaline wherlite, which is thought to be possible source to form an ultrabasic alkaline silicate magma of melilitic to nephelinitic compositions (see Fig. 7). In conclusion, it is believed that melts originated from alkaline wehrlite are probably responsible for the crystallization of different rocks of these complexes.

In addition, Ghatak and Basu (2013) have suggested that the different rocks of the Sung Valley are result of low-degree partial melting of carbonated garnet peridotite, located in the Kerguelen plume. The similar genetic mechanism, i.e. different rock units were formed by batches of independent magmas with distinct magmatic affinity, is also suggested for the Jasra complex (Srivastava and Sinha, 2004b, 2007; Melluso et al., 2012). In a recent study, based on insitu $\mathrm{U}-\mathrm{Pb}$ ages on zircon and perovskite, and $\mathrm{Sr}-\mathrm{Nd}-\mathrm{Hf}$ isotope data on zircon, perovskite, baddeleyite, apatite, titanite and calcite and in-situ Sr-Nd-Hf isotope data on different minerals of the Sung Valley and Jasra complexes, it is suggested that different rock units of these two complexes are not co-genetic and indicate the effects of low-pressure crustal contamination, crystal accumulation and fractional crystallization, rather than mantle-derived heterogeneity (Srivastava et al., 2019).

Not much is known about other alkaline complexes emplaced within the Shillong Plaeau. Nambiar and Golani (1985) have reported a carbonatite and alkaline dykes from the Swangkre area of the Shillong Plateau but no detail information is available except on a potassic lamprophyre dyke, mentioned above. The Mawpyut complex is consisting of cumulate (broadly derivatives of clinopyroxenite, gabbronorite, and gabbro) and non-cumulate (gabbro, monzonite, monzodiorite, and quartzsyenite) units of ultramafic/mafic rocks and minor younger syenitic veins (Chaudhuri et al., 2014). A melanite garnet-bearing nepheline syenite intrusion is also reported from this complex (Maitra et al., 2011). Based on whole rock geochemistry and isotope systematic, Chaudhuri et al. (2014) have suggested that melts generated through partial melting of an enriched mantle source, which later modified due to assimilation and fractional crystallization, have produced the variety of cumulate-noncumulate lithologies of the Mawpyut complex, however more detailed work is required to confirm this assumption.

The Mikir Hills experienced emplacement of two alkaline(carbonatite) complexes in Samchampi (-Samteran) and the Barpung regions (Kumar et al., 1996; Saha et al., 2010, 2017). The Samchampi complex is intruded within the Precambrian basement gneisses and consists of syenite, alkali pyroxenite, ijolite, melteigite, shonkinite, malignite and arbonatite (e.g. Kumar et al., 1989; Saha et al., 2010, 2017). Saha et al. (2017) suggested that a plume-related enriched mantle ( EM II) source was responsible for the genesis of different rocks of the Samchampi complex. Their isotopic signatures are similar to the earlier studied early Cretaceous magmatic rocks such as the Sung Valley, Jasra, Rajmahal-Sylhet and Kerguelen plateau basalts. It is further suggested that different melts generated from melting of an isotopically heterogeneous, metasomatized mantle source produced variety of magmatic silicate and carbonate rocks of the Samchampi alkaline complex. Not much is known for the Barpung complex except that it consists of magnetite-rich pyroxenite, alkali syenite, aegirineaugite bearing fenites, and potassic fenites (Kumar et al., 1996).

\section{Mafic (basic) magmatic rocks}

A number of early Cretaceous mafic magmatism, in the form of the Rajmahal and Sylhet tholeiitic basalts and mafic dykes are also reported from this region. It is believed that all these rocks and alkaline/ ultra-alkaline-carbonatite complexes are part of a protracted LIP event and the Kerguelen plume has played an important role in their genesis (e.g. Baksi, 1995; Kent et al., 1997, 2002; Ghatak and Basu, 2011, 2013; Srivastava et al., 2005, 2014; Chalapathi Rao et al., 2014).

\section{Stable and Radiogenic Isotopic Geochemistry}

\section{Stable isotope geochemistry}

Although no C-O stable isotope data is known for any alkaline 


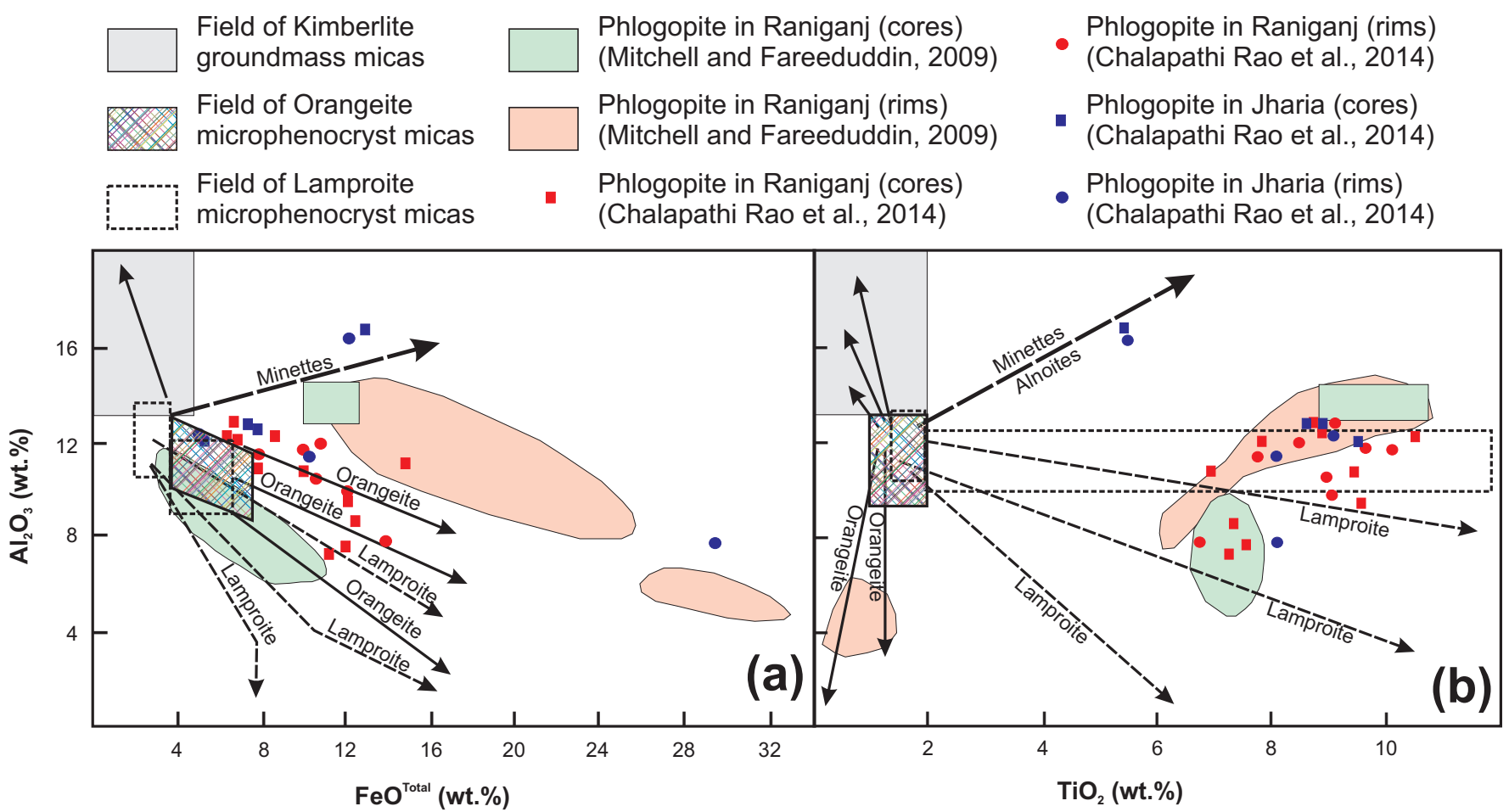

Figure 4. Compositional variations in phlogopites, plotted between (a) $\mathrm{FeO}^{\text {Total }}$ (wt.\%) versus $\mathrm{Al}_{2} \mathrm{O}_{3}(w t . \%)$ and (b) $\mathrm{TiO}_{2}$ (wt.\%) versus $\mathrm{Al}_{2} \mathrm{O}_{3}$ (wt.\%), of the ultra-potassic instrusives from the Damodar valley province, CGC (data taken from Mitchell and Fareeduddin, 2009; Chalapathi Rao et al., 2014). Compositional fields and trends for micas from kimberlite, lamproite, orangeite and minette are taken from Mitchell (1995).
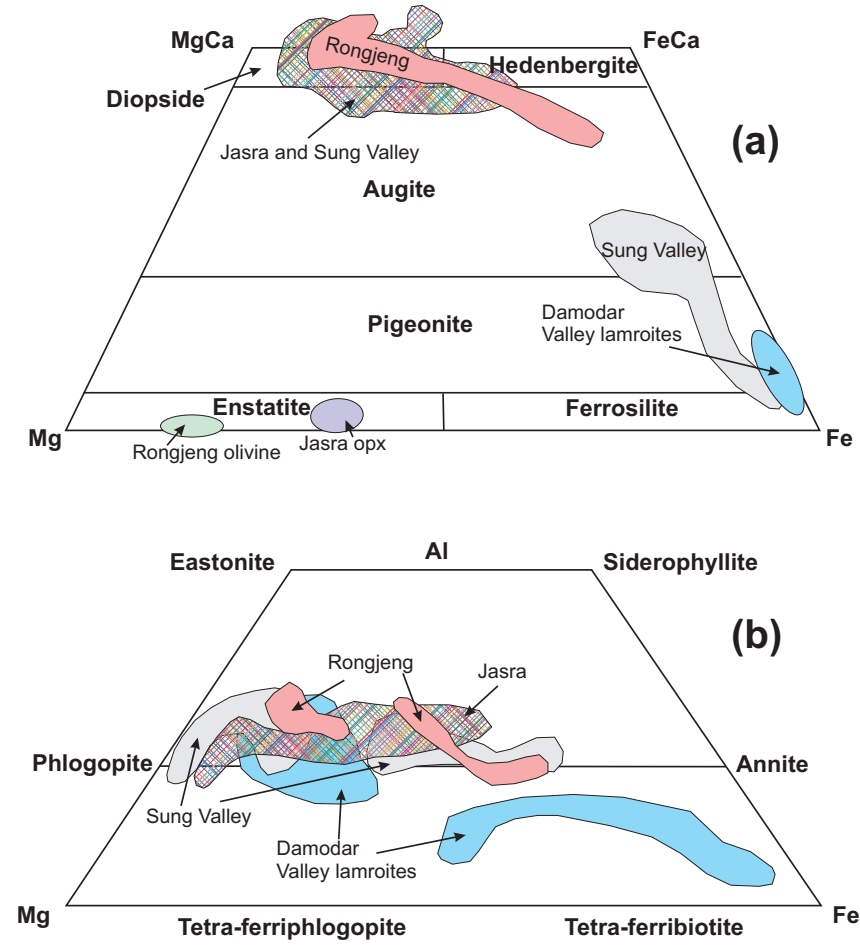

Figure 5. Compositional variations in (a) pyroxene and (b) mica compositions in the Damodar Valley lamproites (Mitchell and Fareeduddin, 2009), Rongjeng potassic lamprophyre (Srivastava et al., 2016), silicate rocks of the alkaline-carbonatite complexes of the Shillong Plateau (Melluso et al., 2010, 2012), plotted on the standard Ca-Mg-Fe (after Morimoto et al., 1988) and Al-Mg-Fe (after Bailey, 1984) ternary diagrams (in wt\%), respectively.

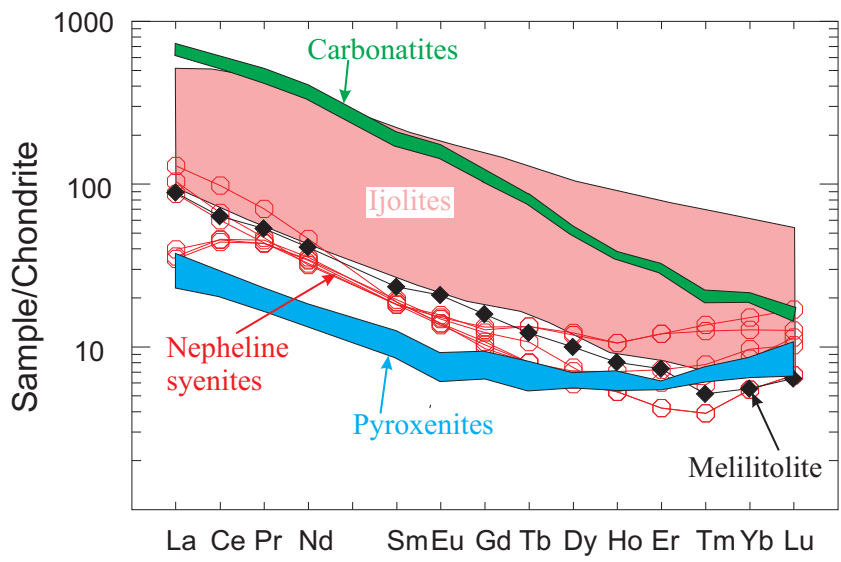

Figure 6. Chondrite normalized rare-earth element patterns for the distinct alkaline silicate rocks and carbonatites of the Sung Valley complex, Shillong Plateau (Srivastava et al., 2005). Chondrite values are after Evensen et al. (1978).

silicate rocks of the region, however, Jia et al. (2003) presented ${ }^{15} \mathrm{~N}$ isotope data for Gondwana lamproites and suggested that their genesis from partial melting of enriched harzburgitic mantle lithosphere during the rifting event. It is also suggested that all lamproites (and other ultrapotassic rocks) have a recycled crustal nitrogen component within their mantle sources during some ancient (Archean) subduction events at the northern margin of the Singhbhum craton (e.g. Jia et al., 2003; Srivastava et al., 2009; Chalapathi Rao et al., 2014).

On the other hand, detailed C-O isotope data are available for the carbonatites of the Shillong plateau (Fig. 8) that show mantle values and clearly discard any role of either crustal assimilation or loss of 


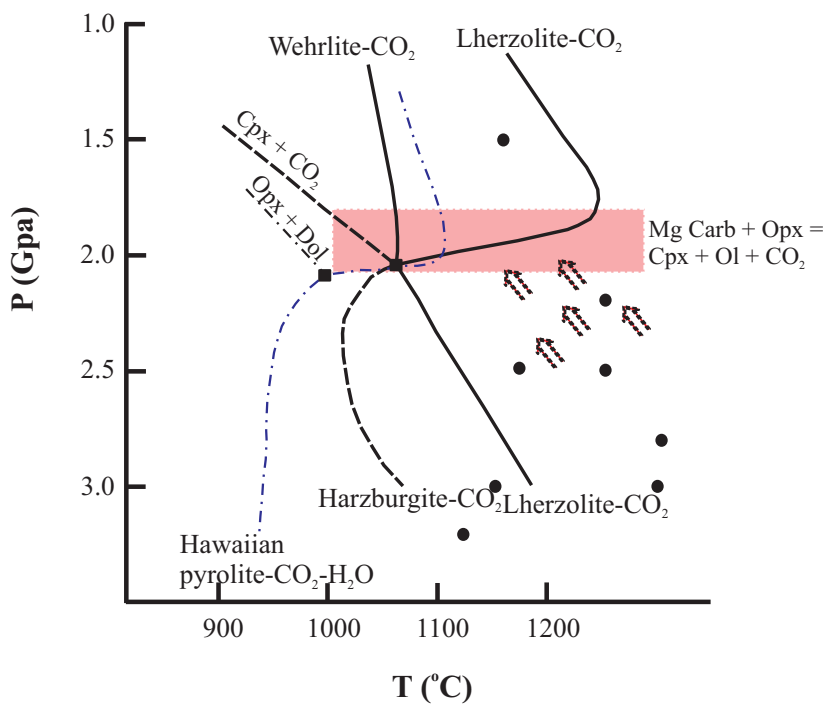

Figure 7. Melting relationship in carbonated peridotitic mantle (after Wallace and Green, 1988; Lee and Wyllie, 1997; Harmer, 1999). Arrows symbolize carbonatitic near-solidus melts ascending through the mantle. At $\sim 20 \mathrm{kbar}$, the melts react concerting mantle lherzolite to werhlite. Black solid dots represent positions of experimental $P-T$ conditions under which carbonate melt exists in equilibrium with peridotite (see Harmer, 1999 for more details). Solid squires represent invariant points marked by the intersection of the relevant solidus curve with the carbonation-decarbonation reaction $\mathrm{Mg} \mathrm{Carb}+\mathrm{Opx}=\mathrm{Cpx}+\mathrm{Ol}+\mathrm{CO}_{2}$.

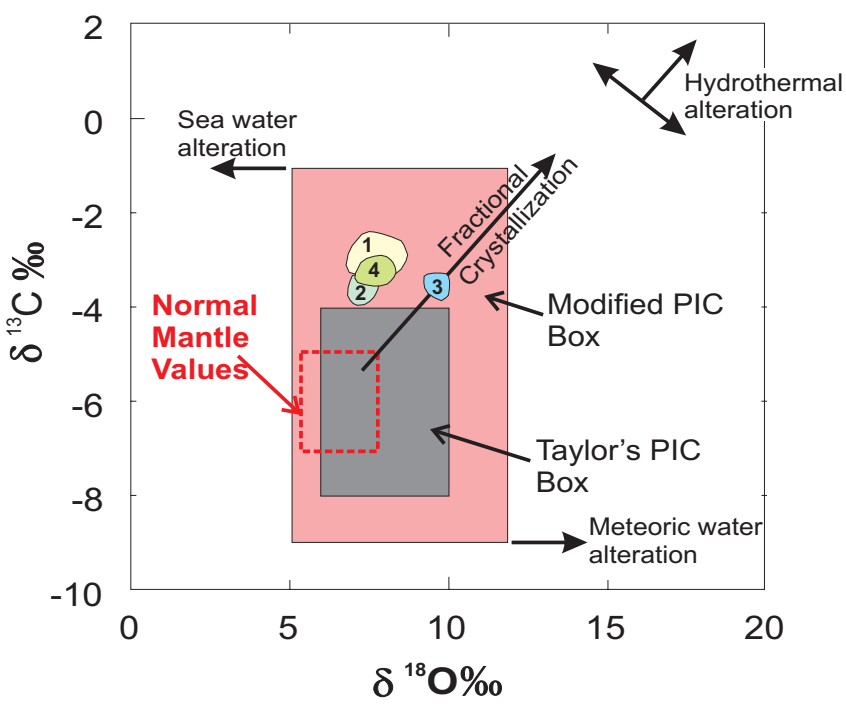

Figure 8. $\delta^{18} \mathrm{O} \%$ and $\delta^{13} \mathrm{C} \%$ plot. Taylor's PIC box after Taylor et al. (1967), modified PIC box after Deines (1989) and Keller and Hoefs (1995), and normal mantle values after Kyser (1990) and Keller and Hoefs (1995). Data source: fields 1, 3 and 4 from Ray et al. (1999) and field 2 from Srivastava et al. (2005).

fluids during emplacement (e.g. Srivastava et al., 2005). Ray et al. (1999) and Ray and Ramesh (2006) have examined all the available C-O isotopic data on the carbonatites from the Sung Valley, Samchampi and Swangkre alkaline complexes and suggested that these early Cretaceous carbonatites are derived from ${ }^{13} \mathrm{C}$ enriched mantle sources. The enrichment probably took place sometime in the
Archean, as also noticed for the lamproites and other ultrapotassic rocks from the CGC (cf. Chalapathi Rao et al., 2014). Almost similar inference has also been suggested on the basis of ${ }^{15} \mathrm{~N}$-isotopic compositions of carbonates, apatites, and magnetites in the Sung Valley carbonatites. It indicates co-existence of at least two nitrogen components in the mantle, i.e. primary and recycled sediments, which suggest that carbonatite magmatism originated from smallscale heterogeneous subcontinental mantle (Basu and Murthy, 2015).

\section{Radiogenic isotope geochemistry}

A fair amount of the bulk-rock $\mathrm{Sr}$ and $\mathrm{Nd}$ isotopic data for lamproitic intrusions (ultrapotassic rocks), carbonatites and associated silicate rocks of the CGC and the SPMH is available (e.g. Middlemost et al., 1988; Rock et al., 1992; Veena et al., 1998; Kumar et al., 2003; Srivastava et al., 2005, 2019; Srivastava and Sinha, 2007; Ghatak and Basu, 2013; Chaudhuri et al., 2014; Saha et al., 2017). Chalapati Rao et al. (2014) have evaluated the available $\mathrm{Sr}$ and $\mathrm{Nd}$ isotopic data on lamproites and suggested (i) their derivation from source regions with long term incompatible element enrichment relative to that of Bulk Earth, and (ii) ${ }^{87} \mathrm{Sr} /{ }^{86} \mathrm{Sr}_{\mathrm{i}}$ and $\varepsilon \mathrm{Nd}_{\mathrm{i}}$ values of these ultrapotassic rocks are different from the primitive Kerguelen plume component but similar to those of the pristine Kerguelen mantle plume derived basalts. Recently, Srivastava et al. (2019) have presented a detailed discussion based on the bulk-rock $\mathrm{Sr}$ and $\mathrm{Nd}$ isotopic data together with recently acquired in-situ $\mathrm{Sr}-\mathrm{Nd}$ isotope data on zircon, perovskite, baddeleyite, apatite, titanite and calcite and also $\mathrm{Hf}$ isotopic data on Sung Valley and Jasra complexes (Fig. 9). They suggested that the effects of low-pressure crustal contamination, crystal accumulation and fractional crystallization, rather than mantle-derived heterogeneity as processes responsible for genesis of these two complexes.

\section{Genesis}

Notwithstanding the suggestion by the earlier workers regarding direct or indirect involvement of the Kerguelen plume in their genesis, the age data is not straightforward to establish any definite emplacement order and probably suggest distinct magma batches were responsible for crystallization of different intrusive/extrusive units. It is also difficult to explain petrogenesis of the wide range of alkaline/ ultra-alkaline silicate and carbonatite rocks and tholeiitic mafic rocks of this region emplaced in the large time span (ca. 17-14 Ma) by any simple process. Srivastava et al. (2019), based on in-situ U-Pb ages and $\mathrm{Sr}-\mathrm{Nd}-\mathrm{Hf}$ isotope data on different minerals from the distinct litho-units of the Sung Valley and Jasra complexes, concluded that plume melting of a heterogeneous mantle to explain the genesis of these rocks is unlikely. This is because the alkaline melts should be generated at lower temperatures than the tholeiitic melts and, obviously, alkaline melts should be generated before or close to the massive tholeiitic event. Furthermore, it is also difficult to explain how a mantle plume could generate a variety of alkaline melts (lamproites, carbonatites + ultra-alkaline and slightly alkaline rocks) at the same time; it also contradicts the petrological/geochemical observations on these rocks. Therefore, it is difficult to establish any causal relationship with the generation of tholeiitic and alkaline magmatism. A wide range of isotopic compositions of alkaline/ultraalkaline silicate and carbonatite rocks from the Shillong Plateau 


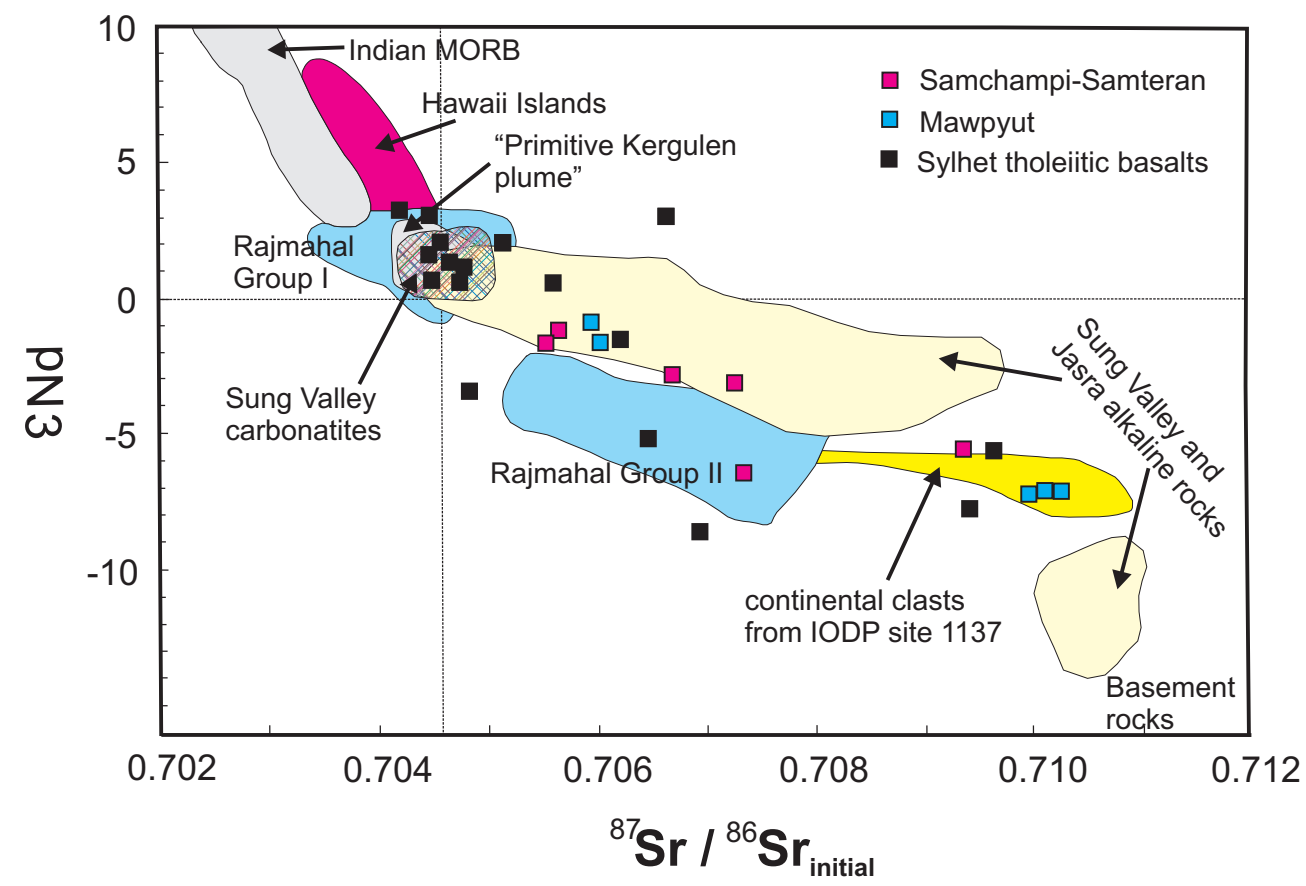

Figure 9. Diagram showing initial $\varepsilon N d$ and ${ }^{87} \mathrm{Sr} /{ }^{86} \mathrm{Sr}$ ratios of whole-rock and minerals for the different early Cretaceous rocks from the eastern and northeastern parts of the Indian Shield (for different fields and data source, refer to Srivastava et al., 2019 and references therein).

Sung Valley, emplaced at $115 \pm 5.1$ Ma, is similar to the Damodar Valley lamproites. These ages are also very close to the ages of the early Cretaceous extrusive and intrusive tholeiitic mafic rocks emplaced within the CGC (ca. 118-112 Ma; see Table 2).

Although this part of the Indian Shield is known for the magmatic emplacements related to the Kerguelen plume during the early Cretaceous, slightly older remnants of the contemporaneous igneous activities in the Southeastern Tibet, Eastern Himalayan syntaxis (Abor volcanic) and Southwest Australia during ca. 138-130 are thought to be connected to the Kerguelen mantle plume and the breakup of the eastern Gondwana as well (Zhu et al., 2009; Olierook et al., 2016, 2017; Singh et al., 2019). Zhu et al. (2009) have categorically emphasized that at the time of emplacement of the Comei LIP, it has occupied a huge area

suggest effects of low-pressure crustal contamination, crystal accumulation and fractional crystallization, rather than mantle-derived heterogeneity and therefore is different from the Rajmahal-Sylhet tholeiitic basalts (Fig. 9).

Different petrogenetic models are presented to explain the genesis of diverse group of early Cretaceous magmatic rocks. Ghatak and Basu (2013) suggest that primitive garnet lherzolite mantle was metasomatised by deep mantle $\mathrm{CO}_{2}$, which also enriched incompatible elements of the garnet peridotite source. Melting of this metasomatised mantle source produced distinct alkalic-mafic-ultramafic-carbonatitic rocks of this region. Srivastava et al. (2019) explains that melts of carbonatite, melilitite and nephelinite compositions can be formed by direct melting of a metasomatized carbonated mantle source, which is also responsible for the crystallization of different silicate rocks after their emplacement in the crust. It is suggested that eruption of the Sylhet-Rajmahal tholeiitic basalts, mafic dykes and lamproites at ca. 118-112 Ma have their possible genetic connection with a mantle plume, however, relatively younger (ca. 109-101 Ma) alkaline carbonatite complexes and lamprophyre of the Shillong Plateau have their derivation from the lowermost parts of the Indian lithosphere and connection with the mantle plume is unlikely.

\section{Possible Connection to the Kerguelen Plume and Large Igneous Province}

The precise radiometric ages (Table 1) for ultrapotassic/ carbonatite-alkaline complexes of this region suggest a prolonged intrusion time (ca. 115-101 Ma). It is observed that Damodar Valley ultrapotassic dykes (mostly lamproites) of the CGC are emplaced slightly earlier (ca. 115-114 Ma) than the most of the litho-units associated to the alkaline-carbonatite complexes and lamprophyre of the Shillong Plateau (ca. 109-101 Ma). An ijolite intrusion of the covering $>40,000 \mathrm{~km}^{2}$; this area will be even larger if considered all the contemporaneous magmatism shown in Figure 10 and, therefore, very rightly qualified for a LIP (cf. Bryan and Ernst, 2008; Ernst, 2014). However, duration of a LIP emplacement is also an important factor. It is recommended that a LIP should be either of short duration ( $<5 \mathrm{Ma}$ ) or consist of multiple short pulses over a maximum lifespan of $50 \mathrm{Ma}$ (Bryan and Ernst, 2008; Ernst, 2014). Therefore, identification of all these short duration magmatic pulses during ca. 140-100 Ma could be a part of the Comie-Bunbury LIP (Zhu et al., 2009), recently identified as the Greater Kurguelen LIP (Olierook et al., 2017), which are directly or indirectly associated to the Kerguelen mega plume (cf. Zhu et al., 2009; Olierook et al., 2016, 2017; Singh et al., 2019).

The Greater Kurguelen LIP include the Comei Province (Zhu et al., 2009), Bunbury Basalt (Olierook et al., 2016), Naturaliste Plateau (Pyle et al., 1995), Wallaby Plateau (Olierook et al., 2015), RajmahalSylhet-Bengal Traps (Kent et al., 2002; Ghatak and Basu, 2011), Abor volcanic (Singh et al., 2019), Beaver Lake-Antarctica (Foley et al., 2002), Elan Bank (Ingle et al., 2002), Broken Ridge (Duncan, 2002), etc. Further, the $\mathrm{Sr}-\mathrm{Nd}-\mathrm{Pb}$ isotopic data on these magmatic events (compiled in Olierook et al., 2017) belonging to the Greater Kerguelen LIP perhaps suggest their derivation from the depleted asthenosphere and lithosphere with negligible contribution from the Kerguelen mantle plume (cf. Olierook et al., 2017); probably mantle plume provided additional heat necessary to melt the asthenosphere and lithosphere. Similar inferences are drawn for the Early Cretaceous alkaline/ultra-alkaline silicate and carbonatite magmatism in this part of the Indian Shield (cf. Srivastava et al., 2019).

\section{Conclusions}

- The early Cretaceous (ca. 118-100 Ma) alkaline/ultra-alkaline silicate and carbonatite magmatism together with 
contemporaneous tholeiitic mafic magmatic events, exclusively recorded from the Damodar Valley and the Shillong Plateau of the eastern/northeastern regions of the Indian Shield, are thought to be associated directly or indirectly with the Kerguelen hot spot that was active in this region during ca. 118-100 Ma.

- Available petrological, geochemical and isotopic data do not suggest any definite emplacement order. They are likely to have derived from distinct magma batches generated through the depleted asthenosphere and lithosphere with negligible contribution from the Kerguelen mantle plume. The latter, however, have possibly provided additional heat necessary to melt the source regions.

- A wide range of isotopic compositions of alkaline/

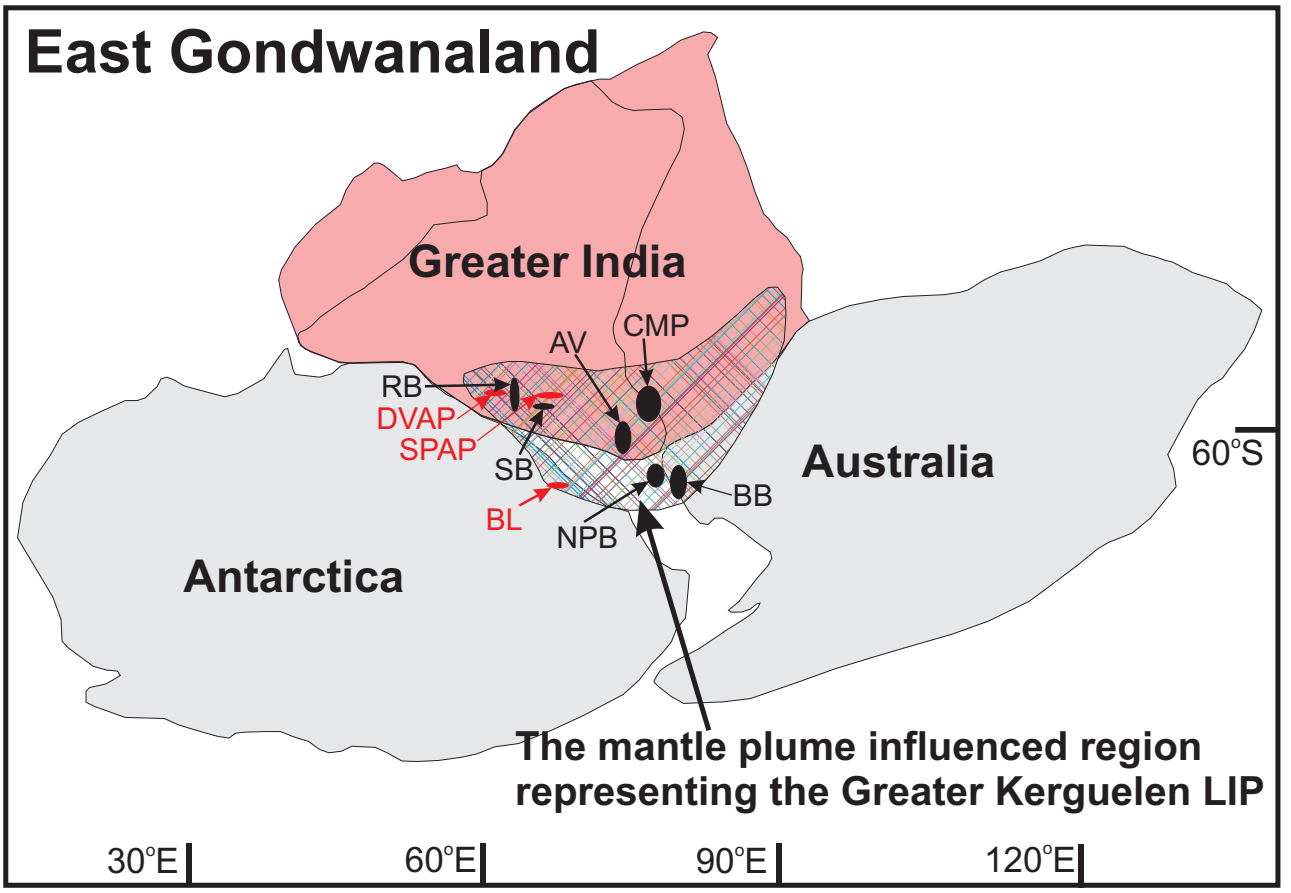

Figure 10. Simplified plate tectonic reconstruction (modified from Zhu et al., 2009) of East Gondwanaland, showing major magmatic events during ca. 140-100 Ma which are supposed to be part of the Greater Kerguelen LIP. Location/events: AV, Abor volcanic; BB, Bunbury basalt; BL, Beaver Lake lamprophyres; CM, Comei magmatic province; DVAP, Damodar Valley alkaline province; NP, Naturaliste Plateau basalt; RB, Rajmahal basalts; SB, Sylhet basalts; SPAP, Shillong Plateau alkaline province. See text for data source.

ultra-alkaline silicate and carbonatite rocks from the Shillong Plateau-Mikir Hills suggest effects of low-pressure crustal contamination, crystal accumulation and fractional crystallization, rather than mantle derived heterogeneity. In this regard they are different from the Rajmahal-Sylhet tholeiitic basalts.

- All these magmatic events together with magmatic events recorded from southeastern Tibet, Eastern Himalayan Syntaxis (Abor volcanic), southwest Australia and eastern Antarctica during the period of ca. 140-100 Ma, have their direct or indirect connection to the Kerguelen mega plume referred to as Greater Kurguelen LIP. This could be connected to the breakup of East Gondwanaland.

\section{Acknowledgements}

Author is thankful to the Science and Engineering Research Board (SERB) for the financial support through a research project (No. EMR/ 2016/000169). Author is grateful to Fareeduddin and an anonymous reviewer for their constructive comments on the earlier version, which improved the MS significantly. Author also thanks the Head, Department of Geology, Banaras Hindu University, for extending all necessary facilities developed with DST-PURSE grant (Scheme 5050) and UGC-CAS-II grant (Scheme 5055) during this work.

\section{References}

Bailey, S.W., 1984, Classification and structures of the micas. Reviews in Mineralogy and Geochemistry, 1984, v. 13, pp. 1-12.
Baksi, A.K., 1995, Petrogenesis and timing of volcanism in the Rajmahal flood basalt province, northeastern India. Chemical Geology, v. 121, pp. 73-90.

Basu, S. and Murty, S.V.S., 2015, Nitrogen and argon in Sung Valley and Ambadongar carbonatite complexes: Evidence of incomplete homogenization of mantle and recycled components. Journal of Asian Earth Sciences, v. 107, pp. 53-61.

Beccaluva, L., Bianchini, G., Natali, C. and Siena, F., 2017, The alkaline-carbonatite complex of Jacupiranga (Brazil): Magma genesis and mode of emplacement. Gondwana Research, v. 44, pp. 157-177.

Bell, K. and Tilton, G.R., 2001, Nd, Pb and Sr isotopic compositions of East African carbonatites: evidence for mantle mixing and plume inhomogeneity. Journal of Petrology, v. 42, pp. 1927-1945.

Bell, K., Kjarsgaard, B.A. and Simonetti, A., 1998, Carbonatite-into the twenty-first century. Journal of Petrology, v. 39, pp.1839-1845.

Bhattacharya, D.K., Mukherjee, D. and Barla, V.C., 2010, Komatiite within Chhotanagpur Gneissic Complex at Semra, Palmau district, Jharkhand: petrological and geochemical fingerprints. Journal of the Geological Society of India, v. 76, pp. 589-606.

Bhowmik, S.K., Wilde, S.A., Bhandari, A., Pal, T. and Pant, N.C., 2012, Growth of the Greater Indian Landmass and its assembly in Rodinia: geochronological evidence from the Central Indian Tectonic Zone. Gondwana Research, v. 22, pp. 54-72

Bryan, S. and Ernst, R.E., 2008, Revised definition of Large Igneous Provinces (LIPs). Earth-Science Review, v. 86, pp. 175-202.

Campbell, I.H., 2005, Large igneous provinces and the mantle plume hypothesis. Elements, v. 1, pp. 265-269.

Chalapathi Rao, N.V., Lehmann, B., Mainkar, D. and Belyatsky, B., 2011, Petrogenesis of the end-Cretaceous diamondiferous Behradih orangeite pipe: implication for mantle plume lithosphere interaction in the Bastar craton, Central India. Contributions to 
Mineralogy and Petrology, v. 161, pp. 721-742.

Chalapathi Rao, N.V., Wu, F.-Y., Mitchell, R.H., Li, L.Q. and Lehmann, B., 2013a, Mesoproterozoic U-Pb ages, trace element and $\mathrm{Sr}-\mathrm{Nd}$ isotopic composition of perovskite from kimberlites of the Eastern Dharwar craton, southern India: Distinct mantle sources and a widespread $1.1 \mathrm{Ga}$ tectonomagmatic event. Chemical Geology, v. 353, pp. 48-64.

Chalapathi Rao, N.V., Kumar, S., Sinha, A. and Srivastava, R.K., 2013b, K-rich titanate from the Jharia ultrapotassic rock, Damodar valley, Eastern India and its petrological significance. The Journal of the Geological Society of India, v. 81, pp. 733-736.

Chalapathi Rao, N.V., Srivastava, R.K., Sinha, A.K. and Ravikant, V., 2014, Petrogenesis of Kerguelen mantle plume-linked Early Cretaceous ultrapotassic intrusive rocks from the Gondwana sedimentary basins, Damodar Valley, Eastern India. Earth-Science Review, v. 136, pp. 96-120.

Chalapathi Rao, N.V., Atiullah, Burgess, R., Nanda, P., Choudhary, A.K., Sahoo, S., Lehmann, B. and Chahong, N., 2016, Petrology, ${ }^{40} \mathrm{Ar} /{ }^{39} \mathrm{Ar}$ age, $\mathrm{Sr}-\mathrm{Nd}$ isotope systematics, and geodynamic significance of an ultrapotassic (lamproitic) dyke with affinities to kamafugite from the eastern-most margin of the Bastar Craton, India. Mineralogy and Petrology, v. 110, pp. 269-293.

Chaudhuri, S., Ray, J., Koeberl, C., Thöni, M., Dutta, R., Saha, A. and Banerjee, M., 2014, Petrology and geochemistry of the ultramafic-mafic Mawpyut complex, Meghalaya: a Sylhet trap differentiation centre in northeastern India. Geological Journal, v. 49 , pp. $111-128$.

Coffin, M.F., Pringle, M.S., Duncan, R.A., Gladezenko, T.P., Storey, M., Mqller, R.D. and Gahagan, L.A., 2002, Kerguelen hotspot magma output since 130 Ma. Journal of Petrology, v. 43, pp. 1121-1139.

Das Gupta, A.B. and Biswas, A.K., 2000, Geology of Assam. Text Book Series, The Geological Society of India, Bangalore, 169 p.

Deines, P., 1989, Stable isotopic variations in carbonatites. In: Bell, K. (Ed.), Carbonatite-Genesis and Evolution. Unwin Hyman, London, pp. 301-359.

Duncan, R.A., 2002, A time frame for construction of the Kerguelen Plateau and Broken ridge. Journal of Petrology, v. 43, pp. 11091119.

Ernst, R.E., 2014, Large Igneous Provinces. Cambridge University Press, $653 \mathrm{p}$.

Ernst, R.E. and Bell, K., 2010, Large Igneous Provinces (LIPs) and carbonatites. Mineralogy and Petrology, v. 98, pp. 55-76.

Evensen, N.M., Hamilton, P.J. and O'Nion, R.K., 1978, Rare earth abundances in chondritic meteorites. Geochimica et Cosmochimica Acta, v. 42, pp. 1199-1212.

Foley, S.F., Andronikov, A.V. and Melzer, S., 2002, Petrology of ultramafic lamprophyres from the Beaver Lake area of Eastern Antarctica and their relation to the breakup of Gondwanaland. Mineralogy and Petrology, v. 74, pp. 361-384.

French, J. E., Heaman, L. M., Chacko, T. and Srivastava, R. K., 2008, 1891-1883 Ma Southern Bastar-Cuddapah mafic igneous events, India: A newly recognized large igneous province. Precambrian Research, v. 160, pp. 308-322.

Ghatak, A. and Basu, A.R., 2011, The Sylhet Traps: vestiges of the Kerguelen plume in NE India. Earth and Planetary Science Letters, v. 308, pp. 52-64.

Ghatak, A. and Basu, A.R., 2013, Isotopic and trace element geochemistry of alkalic-mafic-ultramafic-carbonatitic complexes and flood basalts in NE India: origin in a heterogeneous Kerguelen plume. Geochimica et Cosmochimica Acta, v. 115, pp. 46-72.

Gittins, J. and Harmer, R.E., 2003, Myth and reality in the carbonatitesilicate rock "association". Periodico di Mineralogia, v. 72, pp. 19-26.
Harmer, R.E., 1999, The petrogenetic association of carbonatite and alkaline magmatism: constraints from the Spitskop Complex, South Africa. Journal of Petrology, v. 40, pp. 525- 548.

Heaman, L.M., Srivastava, R.K., Sinha, A.K., 2002, A precise U-Pb zircon/baddeleyite age for the Jasra igneous complex, KarbiAnglong district, Assam, NE India. Current Science, v. 82, pp.744-748.

Ingle, S., Weis, D. and Frey, F.A., 2002, Indian continental crust recovered from Elan Bank, Kerguelen Plateau (ODP leg 183, site 1137). Journal of Petrology, v. 43, pp. 1241-1257.

Jia, Y., Kerrich, R., Gupta, A.K. and Fyfe, W.S., 2003, ${ }^{15} \mathrm{~N}$-enriched Gondwana lamproites, eastern India: crustal $\mathrm{N}$ in mantle source. Earth and Planetary Science Letters, v. 215, pp. 43-56.

Keller, J. and Hoefs, J., 1995, Stable isotope characteristics of recent natrocarbonatite from Oldoiyno Lengai. In: Bell, K. and Keller, J. (Eds.), Carbonatite Volcanism: Oldoinyo Lengai and Petrogenesis of Natrocarbonatite. Springer, Berlin, pp. 113-123.

Kent, R.W., Saunders, A.D., Kempton, P.D. and Ghose, N.C., 1997, Rajmahal basalts, eastern India: mantle source and melt distribution at a volcanic rifted margin. In: Mahoney, J.J. and Coffin, M.F. (Eds.), Large Igneous Provinces - Continental, Oceanic and Planetary Flood Volcanism. Geophysical Monograph Series 100, pp. 145-182.

Kent, R.W., Kelley, S.P. and Pringle, M.S., 1998, Mineralogy and ${ }^{40} \mathrm{Ar} /{ }^{39} \mathrm{Ar}$ geochronology of orangeites (Group II kimberlites) from the Damodar valley, eastern India. Mineralogical Magazine, v. 63, pp. 313-323.

Kent, R.W., Pringle, M.S., Müller, R.D., Saunders, A.D. and Ghose, N.C., 2002, ${ }^{40} \mathrm{Ar} /{ }^{39} \mathrm{Ar}$ geochronology of the Rajmahal basalts, India, and their relationship to the Kerguelen Plateau. Journal of Petrology, v. 43, pp. 1141-1153.

Kumar, D., Mamallan, R. and Dwivedy, K.K., 1996, Carbonatite magmatism in northeast India. Journal of Asian Earth Sciences, v. 13 , pp. $145-158$.

Kumar, A., Dayal, A.M. and Padmakumari, V.M., 2003, Kimberlite from Rajmahal magmatic province: $\mathrm{Sr}-\mathrm{Nd}-\mathrm{Pb}$ isotopic evidence for Kerguelen plume derived magmas. Geophysical Research Letters, v. 30, pp. 2053-2056.

Kyser, T.K., 1990, Stable isotopes in the continental lithospheric mantle. In: Menzies, M. (Ed.), The Continental Lithosphere. Oxford University Press, Oxford, pp. 127-156.

Lee, W.-J. and Wyllie, P.J., 1997, Liquid immiscibility between nephelinite and carbonatite from 1.0 to $2.5 \mathrm{GPa}$ compared with mantle compositions. Contribution to Mineralogy and Petrology, v. 127 , pp. 1-16.

Lehmann, B., Burgess, R., Frei, D., Belyatsky, B., Mainkar, D., Chalapathi Rao, N.V. and Heaman, L.M., 2010, Diamondiferous kimberlites in Central India synchronous with the Deccan flood basalts. Earth and Planetary Science Letters, v. 290, pp. 142149.

Maitra, M., David, J.S. and Bhaduri, S., 2011, Melanite garnet-bearing nepheline syenite minor intrusion in Mawpyut ultramafic-mafic complex, Jaintia Hills, Meghalaya. Journal of Earth System Science, v. 120, pp. 1033-1041.

Melluso, L., Srivastava, R.K., Guarino, V., Zanetti, A. and Sinha, A.K., 2010, Mineral chemistry and petrogenetic evolution of the ultramafic-alkaline-carbonatitic complex of Sung Valley, Northeastern India. The Canadian Mineralogist, v. 48, pp. 205229.

Melluso, L., Srivastava R.K., Petrone, C.M., Guarino, V. and Sinha, A.K., 2012, Mineralogy and magmatic affinity of the Jasra Intrusive Complex, Shillong Plateau, India. Mineralogical Magazine, v. 76, pp. 1099-1117.

Middlemost, E.A.K., Paul, D.K. and Fletcher, I.R., 1988, 
Geochemistry and mineralogy of the minette-lamproite association from the Indian Gondwana. Lithos, v. 22, pp. 31-42.

Mitchell, R.H., 1995, Kimberlites, Orangeites and Related Rocks. Plenum Press, New York, 406 p.

Mitchell, R.H., 2005, Carbonatites and carbonatites and carbonatites. The Canadian Mineralogist, v. 43, pp. 2049-2068.

Mitchell, R.H., 2007, Potassic rocks from the Gondwana coal fields of India: closing Pandora's box of petrological confusion? J. Geol. Soc. India 69, 505-512.

Mitchell, R.H., Fareeduddin, 2009. Mineralogy of the peralkaline lamproites from the Raniganj coalfield, India. Mineral. Mag. 73, 457-477.

Morimoto, N., Fabries, J., Ferguson, A.K., Ginzburg, I.V., Ross,M., Siefert, F.A., Zussman, J., Aoki, K., Gottardi, G., 1988. Nomenclature of pyroxenes. Mineral. Mag. 52, 535-550.

Nambiar AR (1988) Petrology of lamprophyres from parts of East Garo Hills andWest Khasi Hills districts, Meghalaya. The Journal of the Geological Society of India, v. 32, pp. 125-136.

Nambiar, A. R. and Golani, P. R., 1985, A new find of carbonatite from Meghalaya. Current Science, v. 54, pp. 281-282.

Naqvi, S.M. and Rogers, J.J.W., 1987, Precambrian Geology of India. Oxford Monographs on Geology and Geophysics No. 6, Oxford University Press, New York, 233 p.

Olierook, H.K.H., Merle, R.E., Jourdan, F., Sircombe, K., Fraser, G., Timms, N.E., Nelson, G., Dadd, K.A., Kellerson, L. and Borissova, I., 2015, Age and geochemistry of magmatism on the oceanic Wallaby Plateau and implications for the opening of the Indian Ocean. Geology, v. 43, pp. 971-974.

Olierook, H.K.H., Jourdan, F., Merle, R.E., Timms, N.E., Kusznir, N.J. and Muhling, J., 2016, Bunbury Basalt: Gondwana breakup products or earliest vestiges of the Kerguelen mantle plume? Earth and Planetary Science Letters, v. 440, pp. 20-32.

Olierook, Merle, R.E., H.K.H. and Jourdan, F., 2017, Toward a Greater Kerguelen Large Igneous Province: Evolving mantle source contributions in and around the Indian Ocean. Lithos, v. 282283, pp. 163-172.

Pringle, M.S., Storey, M. and Wijbans, J., 1994, ${ }^{40} \mathrm{Ar} /{ }^{39} \mathrm{Ar}$ geochronology of Mid-Cretaceous Indian Ocean basalts: constraints on the origin of large flood basalt provinces. EOS Transactions American Geophysical Union 75 (abstract).

Pyle, D.G., Christe, D.M., Mahoney, J.J. and Duncan, R.A., 1995, Geochemistry and geochronology of ancient southeast Indian Ocean and southwest Pacific Ocean seafloor. Journal of Geophysical Research, v. B100, pp. 22261-22282.

Ramakrishnan, M. and Vaidyanadhan, R., 2010, Geology of India. The Geological Society of India, Bangalore, 994 p.

Ray, J.S. and Pande, K., 1999, Carbonatite alkaline magmatism associated with continental ${ }^{-}$ood basalts at stratigraphic boundaries: cause for mass extinctions. Geophysical Research Letters, v. 26, pp. 1917-1920.

Ray, J.S. and Ramesh, R. 2006, Stable carbon and oxygen isotopic compositions of Indian carbonatites. International Geology Review, v. 48, pp. 17-45.

Ray, J.S., Ramesh, R. and Pande, K., 1999, Carbon isotopes in Kerguelen plume - derived carbonatites: evidence for recycled inorganic carbon. Earth and Planetary Science Letters, v. 170, pp. 205-214.

Ray, J.S., Trivedy, J.R. and Dayal, A.M., 2000, Strontium isotope systematics of Amba Dongar and Sung Valley carbonatite-alkaline complexes, India: evidence for liquid immiscibility, crustal contamination and long-lived $\mathrm{Rb} / \mathrm{Sr}$ enriched mantle sources. Journal of Asian Earth Sciences, v. 18, pp. 585-594.

Ray J. S., Pattanayak S. K. and Pande K., 2005, Rapid emplacement of the Kerguelen plume-related Sylhet Traps, eastern India:
Evidence from 40Ar-39Ar geochronology. Geophysical Research Letters, v. 32, pp. 1-4.

Rock, N.M.S. and Paul, D.K., 1989, "Lamprophyres", "lamproites" and "kimberlites" in India: a bibliography and preliminary reappraisal. The Geological Society of India Memoir, v. 15, pp. 291-311.

Rock, N.M.S., Griffin, B.J., Edgar, A.D., Paul, D.K. and Hergt, J.M., 1992, A spectrum of potentially dimondiferous lamproites and minettes from the Jharia coalfield, eastern India. Journal of Volcanology and Geothermal Research, v. 50, pp. 55-83.

Saha, A., Ganguly, S., Ray, J. and Chatterjee, N., 2010, Evaluation of phase chemistry and petrochemical aspects of SamchampiSamteran differentiated alkaline complex of Mikir Hills, northeastern India. Journal of Earth System Science, v. 119, pp. 675-699.

Saha, A., Ganguly, S., Ray, J., Koeberl, C., Thöni, M., Sarbajana, C. and Sawant, S.S., 2017, Petrogenetic evolution of Cretaceous Samchampi-Samteran Alkaline Complex, Mikir Hills, Northeastern India: Implications on multiple melting events of heterogeneous plume and metasomatized sub-continental lithospheric mantle. Gondwana Research, v. 48, pp. 237-256.

Samal, A.K., Srivastava, R.K., Ernst, R.E. and Söderlund, U., 2019, Neoarchean-Mesoproterozoic mafic dyke swarms of the Indian Shield mapped using Google ${ }^{\mathrm{TM}}$ Earth images and ArcGIS ${ }^{\mathrm{TM}}$, and links with Large Igneous Provinces. In: Srivastava, R.K., Ernst, R.E., Peng, P. (Eds.), Dyke Swarms of the World: A modern perspective, Springer, Singapore, pp. 335-390.

Sarkar, A., Datta, A. K., Poddar, B. K., Bhattacharyya, B. K., Kollapuri, V. K. and Sanwal, R., 1996, Geochronological studies of Mesozoic igneous rocks from eastern India. Journal of Southeast Asian Earth Sciences, v. 13, pp. 77-81.

Sharma, R.S., 2009, Cratons and Fold Belts of India. Springer-Verlag, Heidelburg, $304 \mathrm{p}$.

Simonetti, A., Goldstein, S.L., Schmidberger, S.S. and Viladkar, S.G., 1998, Geochemical and $\mathrm{Nd}, \mathrm{Pb}$, and $\mathrm{Sr}$ isotope data from Deccan alkaline complexes-inferences for mantle sources and plumelithosphere interaction. Journal of Petrology, v. 39, pp. 847-1864.

Singh, A.K., Chung, Sun-Lin, Bikramaditya Singh, R.K., Lee, HaoYang and Khogenkumar, S., 2019, Zircon geochronology, Hf isotopic compositions and petrogenetic study of Abore volcanic rocks of Eastern Himalayan syntaxis, Northeast India: implications for eruption during nreackup of Eastern Gondwana. Geological Journal (Published online); DOI: 10.1002/gj.3477.

Srivastava, R.K. and Sinha, A.K., 2004a, The early Cretaceous Sung Valley ultramafic-alkaline-carbonatite complex, Shillong Plateau, northeastern India: petrological and genetic significance. Mineralogy and Petrology, v. 80, pp. 241-263.

Srivastava, R.K. and Sinha, A.K., 2004b, Geochemistry of early Cretaceous alkaline ultramafic-mafic complex from Jasra, Karbi Anglong, Shillong plateau, Northeastern India. Gondwana Research, v. 7, pp. 549-561.

Srivastava, R.K. and Sinha, A.K., 2007, Nd and Sr isotope systematic and geochemistry of plume related early Cretaceous alkalinemafic-ultramafic-igneous complex from Jasra, Shillong Plateau, Northeastern India. Geological Society of America Special Papers, v. 430 , pp. $815-830$.

Srivastava, R.K., Heaman, L.M., Sinha, A.K. and Shihua, S., 2005, Emplacement age and isotope geochemistry of Sung Valley alkaline-carbonatite complex, Shillong Plateau, northeastern India: implications for primary carbonate melt and genesis of the associated silicate rocks. Lithos, v. 81, pp. 33-54.

Srivastava, R.K., Chalapathi Rao, N.V.C. and Sinha, A.K., 2009, Cretaceous potassic intrusives with affinities to aillikites from Jharia area: Magmatic expression of metasomatically veined and 
thinned lithospheric beneath Singhbhum Craton, Eastern Indian. Lithos, v. 112, pp. 407-418.

Srivastava, R.K., Sinha, A.K. and Kumar, S. 2012, Geochemical characteristics of Mesoproterozoic metabasite dykes from the Chhotanagpur Gneissic Terrain, eastern India: Implications for their emplacement in a plate margin tectonic environment. Journal of Earth System Sciences, v. 121, pp. 509-523.

Srivastava, R.K., Kumar, S., Sinha, A.K. and Chalapathi Rao, N.V., 2014, Petrology and geochemistry of high-titanium and lowtitanium mafic dykes from the Damodar valley, Chhotanagpur Gneissic Terrain, eastern India and their relation to mantle plume(s). Journal of Asian Earth Sciences, v. 84, pp. 34-50.

Srivastava, R.K., Melluso, L. and Sinha A.K., 2016, Petrogenesis of an early Cretaceous potassic lamprophyre dyke from Rongjeng, East Garo Hills, Shillong plateau, north-eastern India. Current Science, v. 110, pp. 649-658.

Srivastava, R.K., Guarino, V., Wu, Fu-Yuan, Melluso, L., and Sinha, A.K., 2019, Evidence of sub-continental lithospheric mantle sources and open-system crystallization processes from in-situ $\mathrm{U}-\mathrm{Pb}$ ages and $\mathrm{Nd}-\mathrm{Sr}-\mathrm{Hf}$ isotope geochemistry of the Cretaceous ultramafic-alkaline-(carbonatite) intrusions from the Shillong
Plateau, north-eastern India: Lithos, v. 330-331, pp. 108-119.

Taylor, H.P., Frechen, J., Degens, E.T., 1967, Oxygen and carbon isotopes studies of carbonatites from the Laacher Sea district, West Germany and the Alno districts, Sweden. Geochimica et Cosmochimica Acta, v. 31, pp. 407-430.

Veena, K., Pandey, B.K., Krishnamurthy, P. and Gupta, J.N., 1998, $\mathrm{Pb}, \mathrm{Sr}$ and $\mathrm{Nd}$ isotopic systematics of the carbonatites of Sung Valley, Meghalaya, northeast India: implications for contemporary plume-related mantle source characteristics. Journal of Petrology, v. 39, pp. 1875-1884.

Wallace, M.E. and Green, D.H., 1988, An experimental determination of primary carbonatite magma composition. Nature, v. 335, pp. 343-346.

Wyllie, P.J. and Lee, W.-J., 1998, Model system controls on conditions for formation of magnesiocarbonatite and calciocarbonatite magmas from the mantle. Journal of Petrology, v. 39, pp. 18851893.

Zhu, D.-C., Chung, S.-L., Mo, X.-X., Zhao, Z.-D., Niu, Y., Song, B. and Yang, Y.-H., 2009, The 132 Ma Comei-Bunbury large igneous province: remnants identi-fied in present-day southeastern Tibet and southwestern Australia. Geology, v. 37, pp. 583-586.

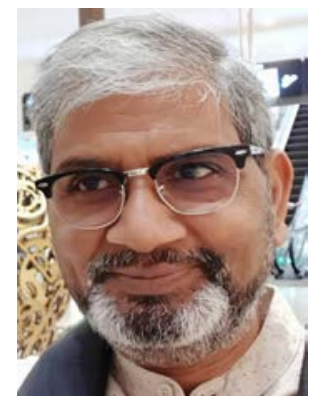

Rajesh K. Srivastava is a Professor at the Banaras Hindu University, Varanasi, India. His specialization includes Igneous Petrology, Geochemistry and Precambrian tectonics, particularly focused on mantle petrology through work on (i) Precambrian Large Igneous Provinces, particularly dyke swarms and their plumbing system, of the Indian shield (ii) ultramafic-alkaline-carbonatite complexes of western, southern, and northeastern India, (iii) lamprophyres, lamproites, and kimberlites from Mahakoshal supracrustal belt, eastern Damodar valley (eastern India) and eastern Dharwar craton, and (iv) The Andaman Ophiolite suite of rocks. Overall, his researches improved our understanding towards deep mantle petrology, particularly nature of SCLM and asthenospheric mantle. 